\title{
KECENDERUNGAN KONVERSI LAHAN DI KAWASAN PENYANGGA KOTA PADANG
}

\author{
M Hagi Akbar ${ }^{1}$, Ahyuni $^{2}$, Yudi Antomi ${ }^{2}$ \\ Program Studi Geografi \\ Fakultas Ilmu Sosial, Univeristas Negeri Padang \\ Email: hagimha@gmail.com
}

\begin{abstract}
Abstrak
Penelitian ini bertujuan untuk 1). mengetahui luas tutupan lahan,2). Kecendrungan konversi lahan dan 3). Kesesuain tutupan lahan dengan RTRW. Metode yang digunakan dalam penelitian ini deskriptif kuantitatif. Data yang digunakan adalah Citra Satelit Landsat TM7 perekaman tahun 2007,tahun 2012 dancitra satelit OLI/TIRS8 tahun 2017 dengan teknikanalisis pansharpening, supervised classification, overlay, dan scoring. Hasil penelitian ini menunjukkan untuk: (1) tutupan lahan terbangun tahun 2007 seluas 642 ha, tahun 2012 seluas 1011 ha dan, 2017 seluas 1472 ha, hutan tahun 2007 seluas 2301 ha, 2012 tahun 2134 ha dan 2017 seluas 2025 ha, kebun campuran 2007 seluas 114 ha, tahun 2012 seluas 181 ha dan tahun 2017 seluas 277 ha, lahan terbuka tahun 2007 seluas 83 ha, tahun 2012 seluas 89 ha dan 2017 seluas 95 ha, sawah tahun 2007 seluas 2351 ha, tahun 2012 seluas 2283 dan 2017 seluas 1965 ha, semak tahun 2007 seluas 693 ha, tahun 2012 seluas 488 ha dan tahun 2017 seluas 402 ha. Dari hasil uji akurasi citra maka di dapatkan overall accuracy 86,72\%. Dan nilai koofisien kappa bernilai $0,8192 \%$.(2) kecendrunga koversi lahan tahun 2007- 2012 adalah bertambahnya lahan terbangun seluas 459 ha, dan kecendrungan konversi lahan tahun 2012 - tahun 2017 adalah bertambahnya lahan terbangun seluas 461 ha (3) hasil overlay kesesuaian tutupan lahan dengan RTRW menunjukan sesuai sebanyak73,20\% dan tidak sesuai $26,80 \%$.
\end{abstract}

KataKunci: Tutupan Lahan, Konversi, Supervised Classification.

\section{Abstract}

This research was purposed to find out: 1) Range of land coverage, 2) Trends of land conversion, and 3) Compatibility between land coverage and RTRW unit. Method used in this research was descriptive quantitative. Data in this research was Landsat TM7 satellite images recorded in 2007 and 2012, and OLI/TIRS8 satellite images recorded in 2017, and data analysis techniques were pans sharpening, supervised classification, overlay, and scoring. Research finding shows that: 1) developed area in 2007, 2012 and 2017, respectively are $642 \mathrm{ha}, 1011 \mathrm{ha}$, and $1472 \mathrm{ha}$; forest area in 2007, 2012 and 2017, respectively are $2301 \mathrm{ha}, 2134 \mathrm{ha}$, and $2025 \mathrm{ha}$; mixed-farm area in 2007, 2012 and 2017, respectively are $114 \mathrm{ha}, 181 \mathrm{ha}$, and 277 ha naked land in 2007, 2012 and 2017, respectively are $83 \mathrm{ha}, 89 \mathrm{ha}$, and $95 \mathrm{ha}$; rice field in 2007, 2012 and 2017, respectively are 2351 ha, $2283 \mathrm{ha}$, and 1965; bushes in 2007, 2012 and 2017, respectively are $693 \mathrm{ha}, 488 \mathrm{ha}$, and $402 \mathrm{ha}$. From precision test of images, it was obtained overall accuracy of $86.72 \%$, and kappa coefficient value was $0.8192 \%$. 2) Trend of land conversion from 2007 to 2012 was developed area addition of $495 \mathrm{ha}$, and trend of land conversion from 2012 to 2017 was developed area addition of 461 ha. 3) Overlay compatibility of land coverage and RTRW unit shows that $73.20 \%$ compatible and $26.80 \%$ incompatible.

Keywords: Land Coverage, Conversion, Supervised Classification.

\footnotetext{
${ }^{1}$ Mahasiswa Program Studi Geografi untuk Wisuda September 2017

${ }^{2}$ Dosen Jurusan Geografi Fakultas Ilmu Sosial Universitas Negeri Padang
} 


\section{PENDAHULUAN}

$\begin{array}{ccc}\text { Permasalahan yang } & \text { sering } \\ \text { tidak } & \text { terhindarkan }\end{array}$ pengembangan wilayah adalah terjadinya konflik penggunaan ruang dan sumberdaya alam, bahkan pada dekade terakhir terlihat kecendrungan konflik pemanfaatan ruang telah mencapai kondisi yang tidak efisien. Pemanfaatan sumberdaya alam dan ruang dan tidak terkendali sebagai akibat meningkatnya perkembangan wilayah dapat menyebabkan kerusakan fungsi lingkungan dan daya dukungnya Aca Sugandhy (1994) dalam Muta'ali (2012).

Hampir seluruh kawasan konservasi di Indonesia berada dalam pola interaksi yang kuat dengan masyarakat yang hidup di sekitarnya. Dimana masyarakat yang tinggal di sekitar kawasan konservasi masih mengandalkan hidupnya pada hutan tersebut. Sebagai contoh masyarakat yang tinggal di daerah penyangga kota padang yang masih berinteraksi dengan kawasan hutan. Aktivitas aktivitas mereka antara lain berburu, berkebundan sebagainya. Kebanyakan aktivitas mereka lambat laun juga akan mengganggu kawasan konservasi itu sendiri akibat meningkatnya kebutuhan yang disebabkan oleh pertambahan jumlah.

Pemanfaatan lahan

pada daerah penyangga berpengaruh terhadap kelestarian kawasan lindung. Penetapan dan pengelolaan zona penyangga harus memperhatikan tiga aspek yaitu ekologi, ekonomi dan sosial budaya masyarakat, hal ini dimaksudkan agar zona penyangga mempunyai nilai ekonomi yang dapat meningkatkan taraf hidup dan persepsi masyarakat dalam menjaga kelestarian kawasan.

Dalam mengelola data perubahan tutupan lahan pemanfaatan
SIG dan data satelit merupakan suatu teknologi yang dapat digunakan untuk mengetahui perubahan tutupan lahan tidak hanya berguna untuk pengelolaan sumber daya alam berkelanjutan, tetapi juga dapat dijadikan suatu informasi dalam merencanakan tata ruang di masa yang akan datang.

Dewasa ini kondisi tutupan lahan Kota Padang yang semakin berkembang, keadaan lahan hijau dikota padang dari tahun ke tahun semakin berkurang terutama di kawasan penyangga. Terjadinya perubahan tutupan lahan apabila tidak segera diatasi, maka dikhawatirkan akan berdampak terganggunya ekosistem pada kawasan penyangga serta timbulnya berbagai masalah, seperti bertambahnya lahan kritis, makin berkurangnya daerah resapan air, terjadinya tanah longsor dan banjir. Penanganan bahaya yang akan terjadi diperlukan langkah awal yaitu melakukan evaluasi tutupan lahan terhadap fungsi kawasan yang telah ditetapkan, sehingga mengurangi dampak dan perubahan alih fungsi lahan.Semakin berkembang nya Kota Padang tentu tutupan lahannya akan terus berubah, sehingga kawasan penyangga akan terus berkurang, dan kawasan penyangga harus diperhatikan

Berdasarkan masalah yang telah dikemukakan maka peniliti mengangkat judul penelitian "Kecendrungan Konversi Lahan di Kawasan Penyangga Kota Padang".

\section{METODE PENELITIAN}

\section{Klasifikasi Citra}

Klasifikasi citra merupakan sebuah teknik intrepetasi citra secara digital dengan mengidentifikasikan suatu objek pada jenis satu tutupan 
lahan, dengan klasifikasi secara terbimbing maka dapat diidentifikasi jenis tutupan lahan berdasarkan data pengideraan jauh dengan menentukan objek, berdasarkan rona, warna, dan fariasi kenampakan objek disekitar sebagai pendukung objek yang dikaji.

\section{Analisis Reginal Poligon (Skoring)}

Penentuan fungsi kawasan dilakukan dengan teknik analisis regional poligon. Baja (2012) menjelaskan, dalam pengertian spasial, analisis regional sebenarnya sama dengan analisis areal (sebagai bentuk analisis titik dan analisi garis)

- Regional analysis dapat dilakukan melalui penilaian isi masing masing areal (dalam hal ini karakteristik ruang/lahan) yang berasal dari tema yang berbeda, atau penentuan nilai treshold suatu area, misalnya lebar/jarak buffer dari sungai atau jalan. Analisis area dapat juga berupa analisis kedekatan (proxy) suatu objek terhadap objek lainnya (misalnya, menentukan jarak antara lahan yang dikembangkan dengan jaringan jalan yang ada).

Untuk lebih memudahkan dalam memahami analisis spasial berbasis poligon, wilayah kerja ditetapkan berdasarkan kriteria dan tata cara penetapan hutan lindung dan hutan produksi sebagaimana di atur dalam surat keputusan Menteri Pertanian

Nomor:

837/Kpts/Um/11/8/1981, serta memperhatikan pula ketentuan dalam Keputusan Presiden Nomor: 48/1983.

Jika mengacu pada skor, jenis penggunaan lahan (fungsi kawasan) ditentukan dengan menjumlahkan nilai nilai skor ketiga faktor diatas serta memperhatikan pula keadan lainnya sebagaimana diurai dalam ketentuan kebijakan di atas.
Pembagian kawasan-kawasan tersebut mengikuti ketentuan skor sebagai berikut:

1. Skor $>175$ :Kawasan Lindung

2. Skor 125 -174 :Kawasan Penyangga

3. Skor < 125: Kawasan Budidaya

Dengan menggunakan analis spasial polygon, indikator dalam penetapan fungsi kawasan dirincikan dalam tabel 2 berikut:

\begin{tabular}{|c|c|c|}
\hline Kriteria Lereng & Klasifikasi & Nilai Skor \\
\hline Kelas 1: $0 \%-8 \%$ & Datar & 20 \\
\hline Kelas 2: $8 \%-15 \%$ & Landai & 40 \\
\hline Kelas $3: 15 \%-25 \%$ & Agak curam & 60 \\
\hline Kelas $4: 25 \%-45 \%$ & Curam & 80 \\
\hline Kelas $5: 45 \%$ atau lebih & $\begin{array}{l}\text { Sangat } \\
\text { curam }\end{array}$ & 100 \\
\hline \multicolumn{3}{|c|}{$\begin{array}{l}\text { Sumber:SK Menteri Pertanian Nomor } 837 / \mathrm{Kpts} / \text { Um } / 11 / 8 / 1981 \text { dalam Baja, } \\
2010 \text {. }\end{array}$} \\
\hline Kriteria Jenis Tanah menurut kepekaannya & Klasifikasi & Nilai skor \\
\hline $\begin{array}{l}\text { Kelas 1: Aluvial, tanah Glei, Planosol, } \\
\text { Hidromorf, Kelabu, Literi air tanah }\end{array}$ & Tidak peka & 1 \\
\hline Kelas 2: Latosol & Agak peka & 30 \\
\hline $\begin{array}{l}\text { Kelas 3: Brown forest soil, non calcic brown, } \\
\text { mediteran }\end{array}$ & Agak peka & \\
\hline $\begin{array}{l}\text { Kelas 4: Andosol, Lateric, Grumusol, Podsol, } \\
\text { Podsolic }\end{array}$ & Peka & \\
\hline Kelas 5: regosol, Litosol,Organosol,Renzina & Sangat peka & 7 \\
\hline
\end{tabular}

\begin{tabular}{|l|l|r|}
\hline Intensitas hujan harian rata-rata & klasifikasi & Nilai skor \\
\hline Kelas $1: \mathrm{s} / \mathrm{d} 13,6 \mathrm{~mm} /$ hari & $\begin{array}{l}\text { Sangat } \\
\text { rendah }\end{array}$ & 10 \\
\hline Kelas $2: 13,6-20,7 \mathrm{~mm} /$ hari & Rendah & 20 \\
\hline Kelas $3: 20,7-27,7 \mathrm{~mm} /$ hari & Sedang & 30 \\
\hline Kelas $4: 27,7-34,8 \mathrm{~mm} /$ hari & Tinggi & 40 \\
\hline Kelas $5: 34,8 \mathrm{~mm} /$ hari atau lebih & $\begin{array}{l}\text { Sangat } \\
\text { tinggi }\end{array}$ & 50 \\
\hline $\begin{array}{l}\text { Sumber:SK Menteri Pertanian Nomor } 837 / \text { Kpts/Um/11/8/1981 dalam } \\
\text { Baja, 2010 }\end{array}$
\end{tabular}

\section{Analisis Overlay Peta}

Untuk mengetahui perubahan dari konversi lahan pada kawasan penyangga dilakukan metode overlay yang merupakan proses dua atau lebih banyak peta dengan area yang sama dan menghamparkan satu dengan yang lain untuk membentuk satu layer peta baru. ArcToolbox merupakan kunci dari program analisis spasial pada software ArcGIS 10.1 dan salah satunya yaitu overlay. Pada menu overlay tersedia beberapa jenis overlay, dalam penelitian ini 
digunakan teknik overlay intersactpemilihan jenis overlay intersact dalam penelitian ini untuk meminimalisir kesalahan data, dalam overlay dengan mempertahankan data asli, biasanya pada overlay peta hasil analisis citra terjadi tumpang susun data yang tidak tepat, dengan memanfaatkan overay intersact dapat dipertahankan data awal dalam analisis. Pada tool spatial analysis tersedia input futures yang merupakan pilihan untuk memasukkan data yang akan dioverlay.

\section{HASIL DAN PEMBAHASAN}

\section{A. Fungsi Kawasan}

Fungsi kawasan terdiri dari tiga jenis, yaitu kawasan lindung, kawasan penyangga, dan kawasan budidaya. Fungsi kawasan tersebut diperoleh dari analisis spasial pada parameter kelerengan, jenis tanah, dan curah hujan. Peta fungsi kawasan didapat dari overlay Peta jenis tanah, Peta lereng, Peta curah hujan. Hasil overlay dari parameter akan menghasilkan fungsi kawasan yang sesuai dengan SK Menteri Pertanian No. 837/Kpts/Um/11/1980 dan No. : 683/Kpts/Um/8/1981.

Dari hasil peta pada gambar 1 maka dapat di jelasakan dengan tabel berikut:

\begin{tabular}{|c|l|r|}
\hline No & \multicolumn{1}{|c|}{ Fungsi Kawasan } & \multicolumn{1}{|c|}{ Luas (ha) } \\
\hline 1 & Kawasan Lindung & 47.679 \\
\hline 2 & Kawasan Penyangga & 6.186 \\
\hline 3 & Kawasan Budidaya & 15.117 \\
\hline Jumlah & 68.982 \\
\hline \multicolumn{2}{|l|}{ Sumber: Hasil overlay peta fungsi kawasan } \\
Fungsi kawasan di Kota
\end{tabular}

Padang di bagi menjadi 3 kawasan yaitu: Kawasan Lindung memiliki luas 47.679 ha, kawasan penyangga seluas 6.186 ha dan kawasan budidaya seluas 15.117 ha

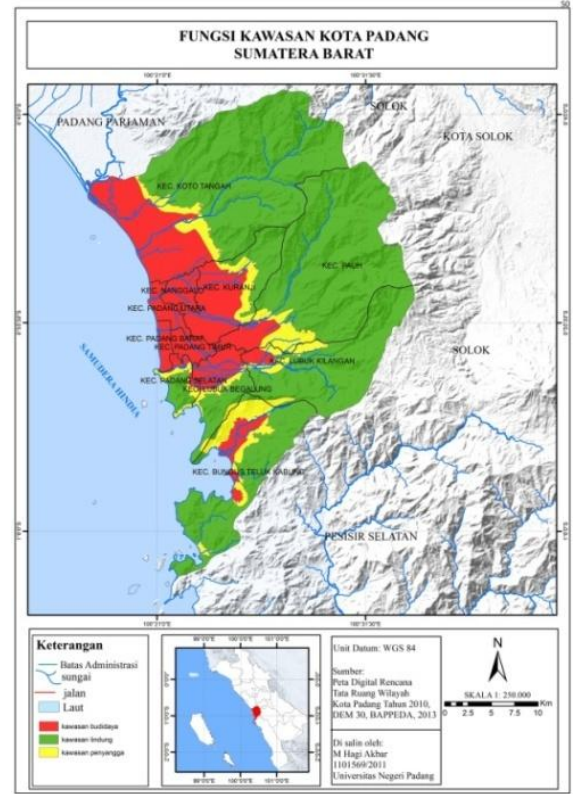

Gambar.1 Peta Fungsi kawasan Kota Padang

\section{B. Jenis tutpan lahan dikawasan Penyangga Kota Padang}

Klasifikasi tutupan lahan di Kawasan penyangga di kota padang menggunakan citra landsat TM 7 tahun 2007, dan Landsat OLI 8 tahun 2017 dengan periode waktu 10 tahun.

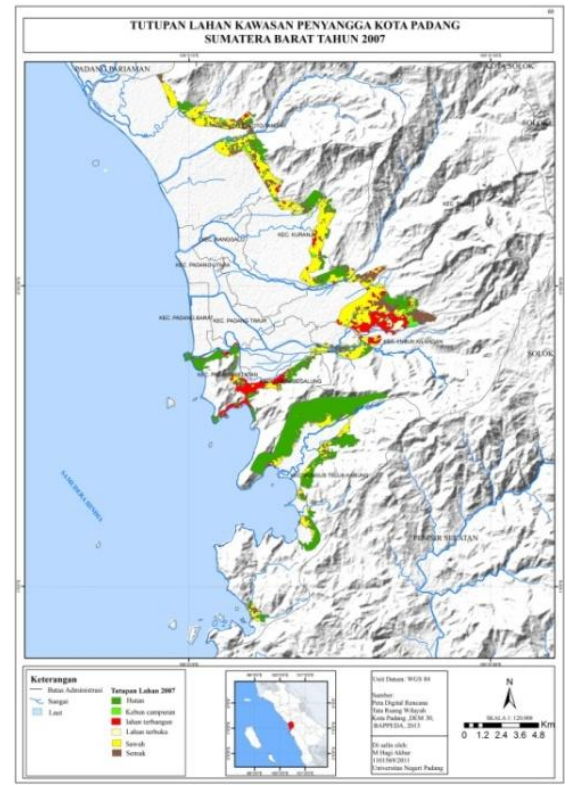

Gambar. 2 Peta tutupan lahan Kawasan Penyangga Kota Padang tahun 2007 


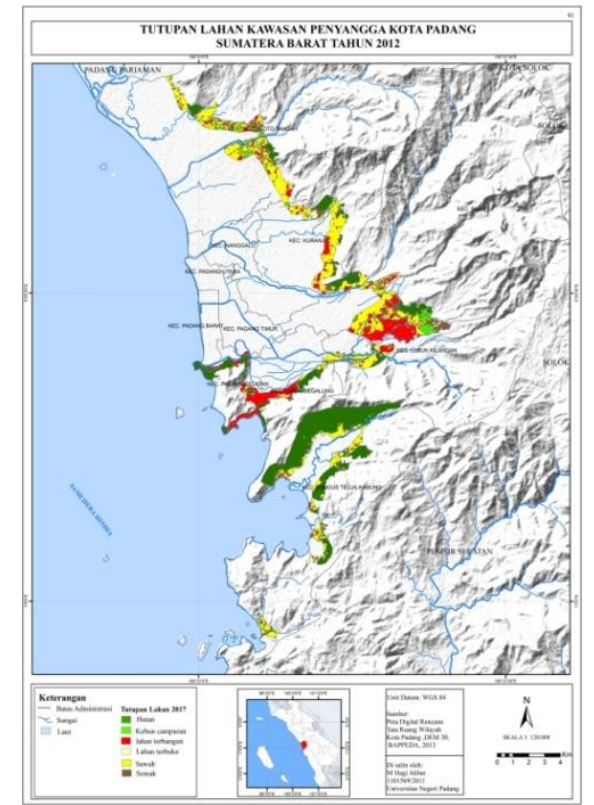

Gambar. 3 Peta tutupan lahan Kawasan Penyangga Kota Padang tahun 2012

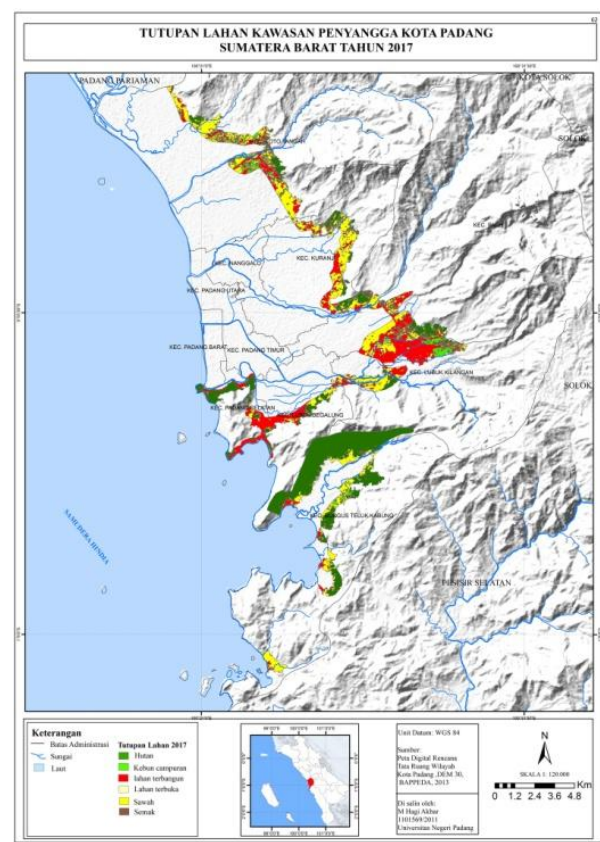

Gambar. 4 Peta tutupan lahan Kawasan Penyangga Kota Padang tahun 2017

Dari peta diatas maka didapat luas tutupan lahan di Kawasan Penyangga Kota Padang sebagai berikut:

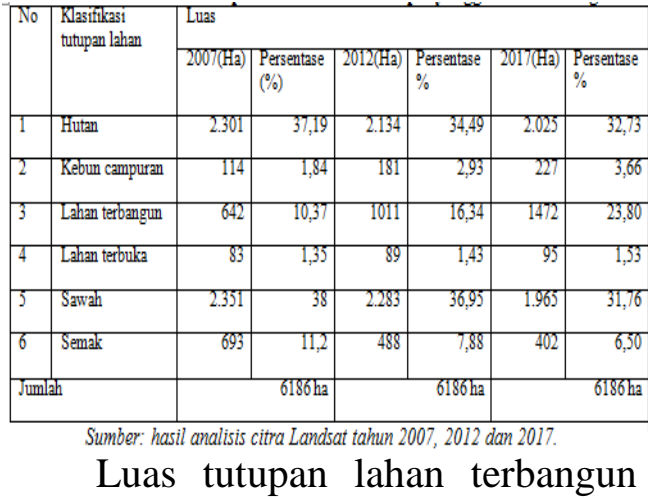

dari tahun 2007 ke tahun 2017 terus meningkat, tahun 2007 luas lahan terbangun 642ha, tahun 2012 seluas 1011 ha dan tahun 2017 menjadi 1472 ha. Lahan terbuka yang ada di kawasan penyangga di kota padang mengalami perkembangan yang tidak terlalu signifikan. Hasil dari klasifikasi perekaman citra satelit periode tahun 2007 - 2017 menujukan pertambahan areal lahan terbuka pada tahun 2007 seluas 83 ha, tahun 2012 seluas 89 ha di tahun tahun 2017 bertambah menjadi 95 ha.

Luas lahan sawah pada tahun 2005 seluas 2351 ha,tahun 2012 seluas 2283 ha dan tahun 2017 berkurang menjadi 1965 ha. Luas hutan di kawasan penyangga tahun 2007 seluas 2301 ha, tahun 2012 seluas 2134 ha dan tahun 2017 berkurang menjadi 2025 ha. Semak belukar luasnya berkurangselama 10 (sepuluh) tahun terakhir ini yang dimulai dari tahun 2007 sebanyak 693 Ha, tahun 2012 seluas 488 dan tahun 2017 berkurang menjadi 402 ha. Luas kebun campuran berkurang dalam 10 (sepuluh) tahun terakhir berikut hasil interpretasi citra pada tahun 2007seluas114Ha, tahun 2012181 ha dantahun $2017227 \mathrm{Ha}$.

Dalam penelitian ini peneliti menggunakan citra Spot 6 dengan resolusi 6 meter dengan metode confusion matrix. Uji akurasi dilakukan antara data training sampel dengan hasil klasifikasi penutupan 
lahan yang diperoleh dari hasil klasifikasi landsat OLI 8 dengan resolusi 15 meter.Hasil dari uji klasifikasi dapat dilihat dari gambar 8 dan 9. Dari hasil uji akurasi citra maka di dapatkan overall accuracy nya bernilai $86,7236 \%$ sehingga dapat dikatakan data yang digunakan valid. Dan nilai koofisien kappa bernilai $0,8192 \%$.

\section{Kecendrungan konversi lahan di Kawasan Penyangga Kota Padang}

Dengan melihat kecendrungan konversi lahan yang terjadi di kawasan penyangga kota padang maka dapat memberikan informasi kepada kita tentang bagaiman arahan pembanguna untuk tahun kedepannya.

Gambar.5 Peta kecendrungan konversi lahan di kawasan penyangga kota padang

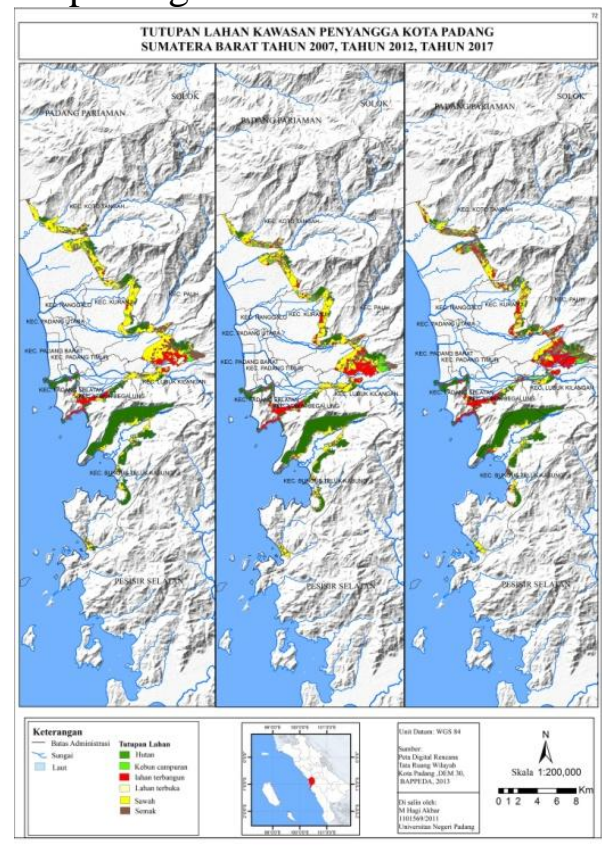

Penjelasan

kecendrungan

konversi lahan dari tahun 2007 sampai tahun 2012 dapat dilihat dari tabel berikut:

\begin{tabular}{|c|c|c|c|c|c|}
\hline No & $\begin{array}{l}\text { Klasifikasi tutupan } \\
\text { lahan }\end{array}$ & Awal (ha) & $\begin{array}{r}\begin{array}{r}\text { Bertambah } \\
\text { (ha) }\end{array} \\
\end{array}$ & $\begin{array}{r}\text { Berkurang } \\
\text { (ha) }\end{array}$ & Alkhir (ha) \\
\hline 1 & Hutan & 2.301 & & 167 & 2.134 \\
\hline 2 & Kebun campuran & 114 & 67 & & 181 \\
\hline 3 & Lahan terbangun & 642 & 369 & & 1011 \\
\hline 4 & Lahan terbuka & 83 & 6 & & 89 \\
\hline 5 & Sawah & 2.351 & & 6) & 2.283 \\
\hline 6 & Semak & 693 & & 205 & 488 \\
\hline Jumla & & 6.186 & & & 6.186 \\
\hline
\end{tabular}

Konversi lahan menjadi lahan terbangun semakin tinggi, makin padatnya areal terbangun di pusat kota, perubahan areal terbangun di kawasan penyangga seluas 369 ha. Selain lahan terbangun tutupan lahan yang bertambah adalah kebun campuran bertambah seluas 67 ha dan lahan terbuka bertambah seluas 6 ha. Luas hutan di kawasan Penyangga Kota padang berkurang seluas 167 ha, perubahan hutan berubah menjadi semak dan sawah, sedangkan sawah mengalami pengurangan seluas 67 ha dan semak berkurang seluas 205 ha.

\begin{tabular}{|c|l|r|r|r|r|}
\hline No & $\begin{array}{l}\text { Klasifikasi tutupan } \\
\text { lahan }\end{array}$ & Awal (ha) & $\begin{array}{r}\text { Bertambah } \\
(\mathrm{ha})\end{array}$ & $\begin{array}{r}\text { Berkurang } \\
\text { (ha) }\end{array}$ & Akhir (ha) \\
\hline 1 & Hutan & 2134 & & 109 & 2025 \\
\hline 2 & Kebun campuran & 181 & 96 & & 277 \\
\hline 3 & Lahan terbangun & 1011 & 461 & & 1472 \\
\hline 4 & Lahan terbuka & 89 & 6 & & 95 \\
\hline 5 & Sawah & 2287 & & 322 & 1965 \\
\hline 6 & Semak & 516 & & 114 & 402 \\
\hline
\end{tabular}

Hasil dari klasifikasi citra tahun 2012 dan 2017 menunjukan terjadinyan konversi tutupan lahan di Kawasan penyangga kota padang adalah bertambahnya lahan terbangun seluas 461 halahan terbangun kebun campuran bertambah seluas 96 ha pertambahan berubahah dari hutan, semak dan sawah, lahan terbuka bertambah seluas 6 ha menjadikan pengurangan lahan sawah seluas 322 ha, semak seluas 114 dan hutan seluas 76 ha 


\section{Kesesuain tutupan lahan kawasan penyangga di kota padang dengan RTRW (Rencana Tata Ruang wilayah) kota Padang}

Perencanaan RTRW kota padang di kawasan penyangga kota Padang dengan tutupan lahan kota Padang masih belum sesuai dengan tutupan lahan di kawasan Penyangga Kota Padang. Kesesuain luas Tutupan Lahan di Kawasan Penyangga di kota Padang yang sudah sesuai seluas 4.528 ha, sedangkan kawasan yang tidak sesuai adalah 1.699 ha, hasil tidak sesuai dengan kesesuaian dengan RTRW kota padang adalah karena adanya rencana RTRW yang tidak sesuai dengan keadaan tutupan lahaan saat ini, adanya perbedaan kesesuain karena masih adanya lahan terbangun di kawasan ruang terbuka hijau pada rencana RTRW kota padang.

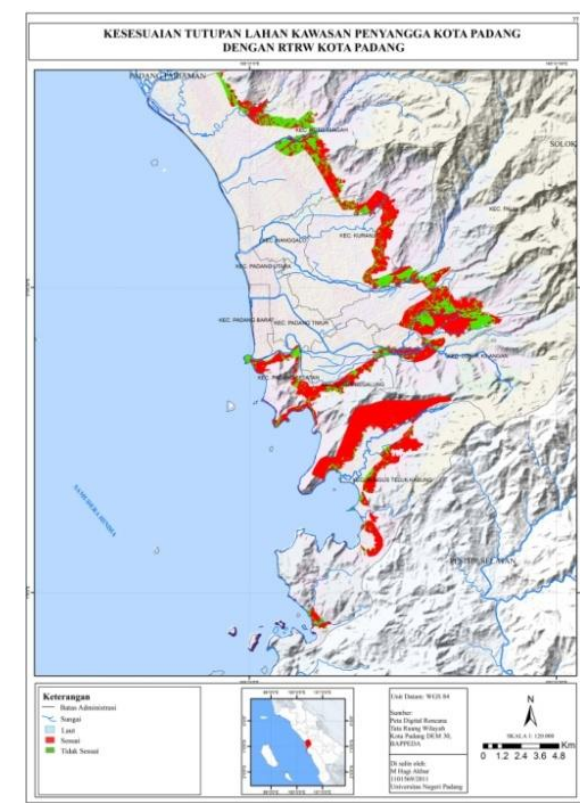

Gambar. 6 Peta kesesuaian Tutupan lahan dengan RTRW Kota Padang

Semakin padatnya areal terbangun di kawasan penyangga akan mengakibatkan rusaknya keseimbangan dan daya dukung kawasan lindung, perencanaan di kawasan penyangga lebih baik dikembangkan sebagai kawasan hijau dan kawasan hutan produksi terbatas agar keseimbangan ekosistem dapat terjaga.

\section{PENUTUP}

\section{Kesimpulan}

1. Perubahan tutupan lahan ini perlu mendapatkan pengawasan dari pemerintah dan instansi yang terkait agar terciptanya lingkungan yang selaras dan melakukan pengarahan pembangunan dan pertambangan agar tidak mengganggu fungsi kawasan yang ada dan merusak lingkungan dan ekosistem yang ada.

2. Sebelum melakukan kebijakan dalam manajemen lahan dan manajemen hutan dengan saran yang telah dikemukakan, perlu dilakukan analisis fungsi kawasan dan merujuk pada ketetapan hutan lindung, produksi fungsi lain, disesuaikan dengan undangundang rencana tata ruang wilayah (RTRW).

\section{DAFTAR PUSTAKA}

Baja Sumbangan. 2012. Perencanaa Tata Guna Lahan dalam Pengembangan Wilayah. Andi Yogyakarta.

Indarto. 2014. Teori Praktek Pengindraan Jauh. Andi Offset: Jakarta.

Khalik Idham, dkk. 2011. Analisis Kelembagaan Pengelolaan Daerah Penyangga Taman Nasional Kerinci Seblat. Jurnal. Bogor. Fakultas Pertanian, IPB.

Lisnawati Yunita dan Wibowo Ari. 2007. Penggunaan Citra 